\title{
COPPER MOBILITY ASSESSMENT USING SPECIATION SCHEMES: CASE STUDY-MANTRIJERON DISTRICT, YOGYAKARTA, INDONESIA
}

\author{
Phetnakhone Xaixongdeth*1 ${ }^{*}$, Heru Hendrayana ${ }^{1}$, Doni Prakasa Eka Putra ${ }^{1}$, Dwikorita \\ Karnawati $^{1}$, and Tsutomu Sato ${ }^{2}$ \\ ${ }^{1}$ Department of Geological Engineering, Gadjah Mada University, Yogyakarta, Indonesia \\ ${ }^{2}$ Laboratory of Environmental Geology, Faculty of Engineering, Hokkaido University, Kita 13 Nishi 8, Kita-Ku, \\ Sapporo 060-8628, Japan
}

\begin{abstract}
Heavy metals mobility in soils is controlled by many factors such physical and chemical properties, especially mineralogical composition of such environment. This study focused on the mineralogical of two soils types (fine sandy loam and loamy fine sand) to retain/mobile $\mathrm{Cu}$. Two non contaminated soils from Yogyakarta urban area, Indonesia, were artificially contaminated with $\mathrm{Cu}$ solution. Subsequently, soils artificially contaminated were extracted from various geochemical phases of soil by sequential extraction procedure. The results show that both of soils types can retain $\mathrm{Cu}$ well with maximum is $5.8 \mathrm{mg} / \mathrm{g}$ of loamy fine sand and $3.9 \mathrm{mg} / \mathrm{g}$ of fine sandy loam. Additionally, the iron amorphous phase content in clay fraction is influence $C u$ retains in these soils. This is advantage in environment of Yogyakarta urban area, Indonesia, where this area underlain by loamy sand soil.
\end{abstract}

Keywords: Copper, mobility, iron, sequential extraction.

\section{Introduction}

Last few decades, environmental effects due to urbanization and industrialization extend very

${ }^{*}$ Corresponding author: P. XAIXONGDETH, Department of Geological Engineering, Faculty of Engineering, Gadjah Mada University, Jl. Grafika 2 Yogyakarta, 55281, Indonesia. E-mail: phetxai@yahoo.com fast. Both surface water and groundwater is mainly vulnerable to contaminate from discharge of waste-water by various industries, especially in developing countries. Heavy metals is major contaminant from industry area, which represents a serious problem to environment due to their great toxicity (Bhagure and Mirgrane, 2001). Since copper is not only widespread toxic metal to environments but also "soft or intermediately soft" toxic metals. Therefore, $\mathrm{Cu}$ release and retain to soil much concern. Understanding of copper mobility can provide important information for remediating contamination sites as well as land use planning.

Geochemical process is an important factor control in heavy metal mobile or retain in the soil. The knowledge of how contaminants partition among the various geochemical phases allows for better insight into the mechanisms of heavy metals retention and mobile (Cabral and Lefebvre, 1998). In the past, several chemical extraction processes have been investigated for various propose (Gibson and Farmert, 1986; ANZECC and ARMCANZ, 2000; Plassard et al, 2000; Mullerova et al, 2003; Snape et al, 2004; Al-Zahrani and Kennichi et al, 2008; AbdulMajid, 2009) such as heavy metals retention in soil/heavy production in soil, retention phase.

This study is dealing with Copper migration 
through the soils which lead to groundwater contamination. The technique of sequential extraction (Tessier et al, 1979 and Kennichi et al, 2008) was employed to assist in the determination of the partitioning of Copper, among of the geochemical phases in fine sandy loam and loamy fine sand, commonly found in urban area of Yogyakarta, Indonesia.

\section{Background}

Yogyakarta City is situated in Yogyakarta Special Province, Central Java Island, Indonesia, an educational, a cultural and a tourism city in Indonesia. To its north is Merapi Volcano (peak of the volcano reaches the elevation of $2911 \mathrm{~m}$ above sea level, Karnawati et al, 2006) and to its south is the Indian Sea. Based on the population census conducted in the year 2004, the population of the city has reached the numbers of $3,257,000$ with the growth rate of $0.39 \%$. Population density was $12,206.5 / \mathrm{km}^{2}$ at the city (Karnawati et al, 2006). The high population growth in Yogyakarta is attributed to the high number of people that migrates into this city every year. Many establishments such as home stays, shopping center, hotels, industry and schools had been built. Since the result of population increase, the requests of humans for natural resources also increase which may cause quite serious problems of environmental degradations. One of the most important resources in Yogyakarta is shallow groundwater.

Mantrijeron District or the study areas is specifically located in the south part of Yogyakarta Special Province with elevation is 90$100 \mathrm{~m}$ above the sea level (Figure 2). The study area mostly covers by batik home industry areas and hotel approximately covering 30 ha.

\section{Materials and methods}

\subsection{Materials}

Two soil samples (loamy fine sand and fine sandy loam) were collected from surface depth to water table, at Mantrijeron District, Yogyakarta, Indonesia where batik home industry is dominant within this area. Two soil samples are group of sand and loamy with low clay
Table 1: Soil properties of soils at Mantrijeron District, Yogyakart Indonesia.

\begin{tabular}{|c|c|c|}
\hline \multicolumn{3}{|c|}{ Soil Properties } \\
\hline Properties & $\begin{array}{c}\text { Fine sandy } \\
\text { loam }\end{array}$ & $\begin{array}{c}\text { Loamy } \\
\text { fine sand }\end{array}$ \\
\hline Bulk density (rb) & 2.02 & 1.83 \\
\hline Dry density (rd) & 1.62 & 1.56 \\
\hline Porosity, n (\%) & 40.37 & 43.46 \\
\hline $\begin{array}{l}\text { Volumetic water } \\
\text { content, V }(\%)\end{array}$ & 40.5 & 27.92 \\
\hline Specific gravity & 2.72 & 2.75 \\
\hline \multicolumn{3}{|l|}{ Gran size } \\
\hline Gravel (\%) & 0.61 & 7.81 \\
\hline Sand $(\%)$ & 70.87 & 73.99 \\
\hline Silt/Clay $(\%)$ & 28.52 & 18.21 \\
\hline Permeability $(\mathrm{m} / \mathrm{sec})$ & $6.40 \mathrm{E}-06$ & $4.80 \mathrm{E}-06$ \\
\hline
\end{tabular}

fraction content. Loamy fine sand were collected from a depth of $1.6 \mathrm{~m}$, while fine sandy loam were collected at the same location from a depth of $3.2 \mathrm{~m}$. Soil properties were summary in Table 1. The soil samples were freeze-dried and sieved under $2 \mathrm{~mm}$ before being stored for the subsequent experiment. After that, soil samples were measured mineralogy and chemical composition/extractable metals. Mineral phase and mineral chemical composition were identified by X-ray diffraction (XRD) analysis using RINT-2100V/PC diffractometer (Rigaku, Japan), although soil properties of both soils are different but mineralogy is similar (Figure ??). The main mineral of these soil are anorthite, albite, and small amount of kaolinite and amorphous iron, while energy dispersive $\mathrm{X}$ ray fluorescence spectrometer, Xepos (Rigaku, Japan) was identified for chemical composition; the major chemical composition of these soil are $\mathrm{Si}, \mathrm{Al}, \mathrm{Ca}$ and Fe which average chemical compositions were shown in Table 2. Detection of high quantity of iron in these soils (Table 2) indicated that iron oxide is an important component of these soils.

\subsection{Batch experiments}

Soil samples were sieve under $2 \mathrm{~mm}$ for artificial soils procedure. Artificial soil contaminant 


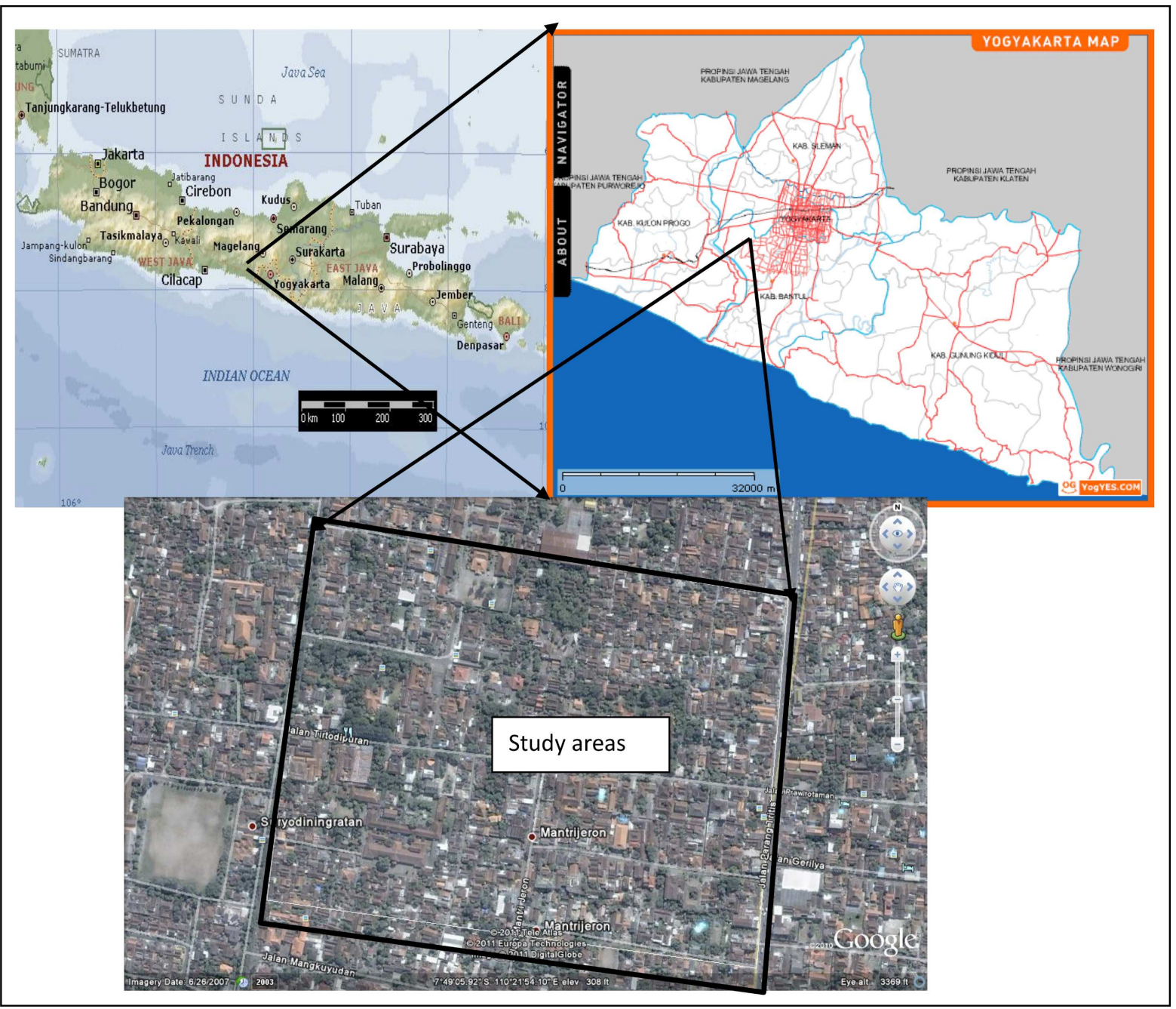

Figure 1: Study area.
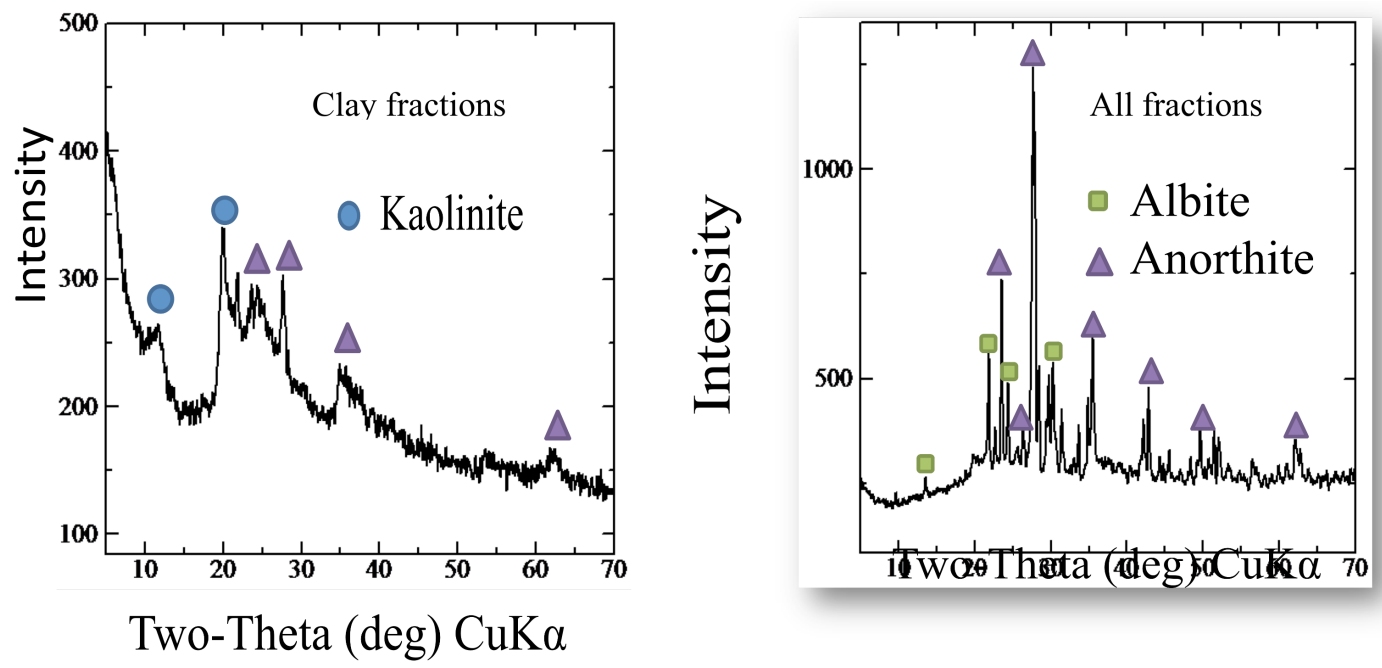

Figure 2: XRD pattern of soil at study area. 
Table 2: Average Chemical Composition of Soil at Mantrijeron Dicstrict.

\begin{tabular}{|l|c|}
\hline Chemical composition & Weight (\%) \\
\hline $\mathrm{SiO}_{2}$ & 56.3 \\
\hline $\mathrm{Al}_{2} \mathrm{O}_{3}$ & 21.67 \\
\hline $\mathrm{CaO}$ & 8.03 \\
\hline $\mathrm{Fe}_{2} \mathrm{O}_{3}$ & 6.99 \\
\hline $\mathrm{Na}_{2} \mathrm{O}$ & 2.59 \\
\hline $\mathrm{MgO}$ & 1.37 \\
\hline $\mathrm{TiO}_{2}$ & 0.64 \\
\hline $\mathrm{P}_{2} \mathrm{O}_{5}$ & 0.32 \\
\hline $\mathrm{MnO}$ & 0.18 \\
\hline $\mathrm{SO}_{3}$ & 0.04 \\
\hline $\mathrm{Cl}$ & 0.02 \\
\hline $\mathrm{V}_{2} \mathrm{O}_{5}$ & 0.03 \\
\hline $\mathrm{Co} \mathrm{O}_{3}$ & 0.02 \\
\hline $\mathrm{CuO}$ & 0.01 \\
\hline $\mathrm{ZnO}$ & 0.02 \\
\hline $\mathrm{SrO}$ & 0.05 \\
\hline $\mathrm{BaO}$ & 0.01 \\
\hline $\mathrm{PbO}$ & 0 \\
\hline
\end{tabular}

by $\mathrm{Cu}$ solution were perform by batch sorption experiments, $3 \mathrm{~g}$ freeze-dried soils were added to $12 \mathrm{~mL}$ of $\mathrm{CuSO}_{4}(2 \mathrm{mM})$ solution in centrifuge tube and shake for 24 hours, the separation did by centrifuge 3000rpm for 20 minutes and filtered by $0.2 \mu \mathrm{m}$ membrane filter (Figure 3). The amount of $\mathrm{Cu}$ in solution was measured by ICPAES. freeze-dry. Finally, all soil samples will and stored for sequential extraction.

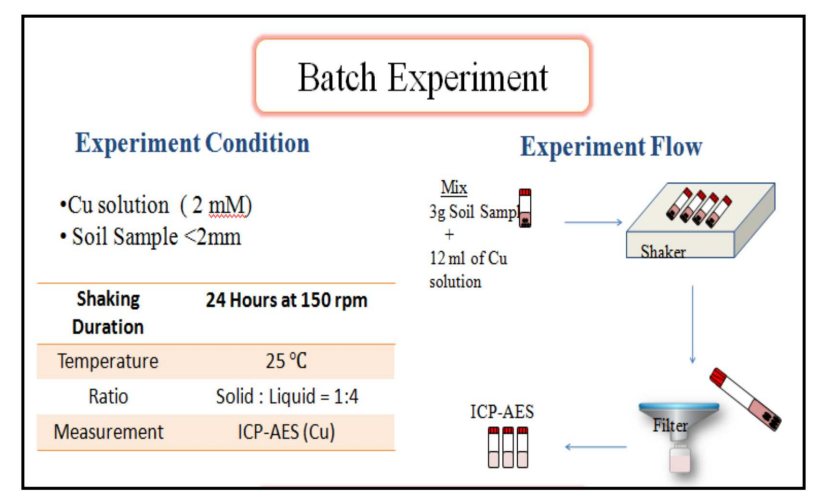

Figure 3: Batch experiment flow.

\subsection{Chemical extraction}

All fraction and clay fraction of soil samples were extracted metal in geochemical phases except the one that bound to silicate by mixing $6 \mathrm{M}$ $\mathrm{HCl}$ solution (ANZECC and ARMCANZ, 2000 and Snape et al, 2004) with grained dry-freez soil into ratio $1: 1000$ of solid:solution at $80^{\circ} \mathrm{C}$ for $2 \mathrm{hr}$. All metals were separated by centrifuge $3000 \mathrm{rpm}$ for 20 minutes and filtered by $0.2 \mu \mathrm{m}$ membrane filter. Finally, $\mathrm{Cu}$ concentrations of each step were measured by ICP-AES.

Clay fraction of soil samples were extracted metal that bound to to amorphous, poor crystalline Iron Aluminum minerals by mixing $0.2 \mathrm{M}$ Ammonium oxalete solution ( $\mathrm{pH} 3.0$ ) into ratio 1:600 (solid:solution) at room temperature for $2 \mathrm{hr}$ with darkness condition. This extraction call TAO extraction (Kennichi et al, 2008).

\subsection{Sequential extraction}

In past decades, sequential extraction was performed to strengthen heavy metals bonding onto mineral surfaces in many fields of researches (Tessier et al, 1979; Plassard et al, 2000; ANZECC and ARMCANZ, 2000; Mullerova et al, 2003; Kennichi et al, 2008). In this study, artificial soil contaminant was prepared by ground to become powder, soil samples $(2 \mathrm{~g})$ from batch experiments were processed five steps of extraction from Kennichi, et al (2008) (Table 3) to determine the dominant form of $\mathrm{Cu}$ in the soil.

(F1) Water extraction: metal phases soluble with water. By mixing dieonized water (pH 5.8-6.3) into ratio 1:10, $2 \mathrm{~g}$ of soil with $20 \mathrm{ml}$ of deionized water at room temperature for $6 \mathrm{hr}$.

(F2) $\mathrm{MgCl}$ extraction: the residue from (F1) were added to $1 \mathrm{M} \mathrm{MgCl}_{2}$ solution ( $\mathrm{pH} 7.0$ ) into ratio 1:25 (solid:solution) at room temperature for $4 \mathrm{hr}$, apportion of exchangeable matals was obtained.

(F3) TAO extraction: the residue from (F2) was added to $0.2 \mathrm{M}$ Ammonium oxalete solution ( $\mathrm{pH}$ 3.0) into ratio 1:600 (solid:solution) at room temperature for $2 \mathrm{hr}$ with darkness condition, metals bound 
to amorphous, poor crystalline iron and aluminum minerals were acquired.

(F4) CDB extraction: metals bound to iron minerals were obtained by mixing the residue from (F3) with $0.3 \mathrm{M}$ Sodium acid citrate, $0.2 \mathrm{M}$ Sodium hydrogen carbonate and $0.1 \mathrm{~g} / \mathrm{L}$ Sodium dithionite $(\mathrm{pH}$ 8.5) into ratio $1: 100$ of solid:solution at $80^{\circ} \mathrm{C}$ for 30 $\min$.

(F5) $\mathrm{HCl}$ extraction: the residue from (F4) was mixed with $6 \mathrm{M} \mathrm{HCl}$ into ratio 1:1000 of solid:solution at $80^{\circ} \mathrm{C}$ for $2 \mathrm{hr}$, metals bound to clay mineral was gained.

In each step, the separation did by centrifuge $3000 \mathrm{rpm}$ for 20 minutes and filtered by $0.2 \mu \mathrm{m}$ membrane filter. Finally, $\mathrm{Cu}$ concentrations of each step were measured by ICP-AES. Summary of Sequential extraction steps are shown in Table 3 and Figure 4 .

\section{Result and Discussion}

\subsection{Batch experiment}

The results of batch experiment show that loamy fine sand and fine sandy loam take up almost $100 \%$ of $\mathrm{Cu}$ from solution within one hour $(99.95 \%$ of loamy fine sand; and $99.93 \%$ of fine sandy loam). Based on Xaixongdeth et al, (2012), the Cu uptake capacity of soil in the study area is correlated to the clay fraction, high clay fraction content is observed in loamy fine sand $(6.61 \%)$ and fine sandy loam (4.69\%), while lower clay content characterizes sandy loam $(2.78 \%)$ and sand $(1.89 \%)$. maximum $\mathrm{Cu}$ sorption capacity in loamy fine sand and fine sandy loam is $5.8 \mathrm{mg} / \mathrm{g}$ and $3.9 \mathrm{mg} / \mathrm{g}$, respectively.

\subsection{Chemical extraction}

The amount of metals from metals extraction was agreed to XRF result which $\mathrm{Al}$ and $\mathrm{Fe}$ is main chemical composition in these soil, the summary of the result of metals extraction are shown in Table 4.

In clay fractions, the amounts of $\mathrm{Cu}$ that can be extracted from in amorphous iron phase were similar to amount of $\mathrm{Cu}$ that obtained from metals extraction. Loamy fine sand, $\mathrm{Cu}$ that detected from metals extraction is 164 $\mathrm{mg} / \mathrm{kg}$ whereas in amorphous iron phase $\mathrm{Cu}$ detection is $175 \mathrm{mg} / \mathrm{kg}$. Fine sandy loam, $\mathrm{Cu}$ detection in metals extraction is $61.2 \mathrm{mg} / \mathrm{kg}$ while $\mathrm{Cu}$ that detected from in amorphous iron phase is $91.8 \mathrm{mg} / \mathrm{kg}$. Although that $\mathrm{Cu}$ from TAO extraction were higher than $\mathrm{HCl}$ extraction, the reason could be because of soil samples that was take for both $\mathrm{TAO}$ and $\mathrm{HCl}$ extraction was dry and grinded in different time which could be give a little different between TAO and $\mathrm{HCl}$ extraction. This can be prove that in natural soil of loamy fine sand and fine sandy loam from Mantrajeron, Yogyakarta, Indonesia, $\mathrm{Cu}$ sorption to these soil are influence by iron amorphous. Metals bound to clay fraction in loamy fine sand and fine sandy loam are shown in Table 5 .

\subsection{Sequential extraction}

The result of sequential extraction showed that copper sorption to many phases in different amount. This experiment copper sorption mainly influenced by iron amorphous phase which copper detected in this phase is $86.4 \%$ $(648 \mathrm{mg} / \mathrm{kg})$ in loamy fine sand and around $65 \%(492.6 \mathrm{mg} / \mathrm{kg})$ in fine sandy loam. In exchangeable phase and iron mineral phase, $\mathrm{Cu}$ detect in fine sandy loam better than fine sandy loam. Loamy fine sand could detect $\mathrm{Cu}$ $3.3 \%(24.77 \mathrm{mg} / \mathrm{kg})$ in exchangeable phase and $2.84 \%(21.3 \mathrm{mg} / \mathrm{kg})$ in iron mineral phase, while fine sandy loam could retain $\mathrm{Cu}$ 15.37\% (116.75 $\mathrm{mg} / \mathrm{kg}$ ) in exchangeable phase and $16.07 \%$ $(122 \mathrm{mg} / \mathrm{kg})$ in iron mineral phase. In contrast with exchangeable and iron mineral phase, clay mineral phase, $\mathrm{Cu}$ that detect in loamy fine sand higher than fine sandy loam, 7.41\% (55.6 $\mathrm{mg} / \mathrm{kg})$ and $3.68 \%(28 \mathrm{mg} / \mathrm{kg})$, respectively. Overall of the result of sequential extraction, $\mathrm{Cu}$ sorption in loamy fine and fine sandy loam are mainly in amorphous iron phase which agreed to chemical extraction, although that in another phases the result were different. The details of $\mathrm{Cu}$ distribution in these soils are shown on Figure 5. 


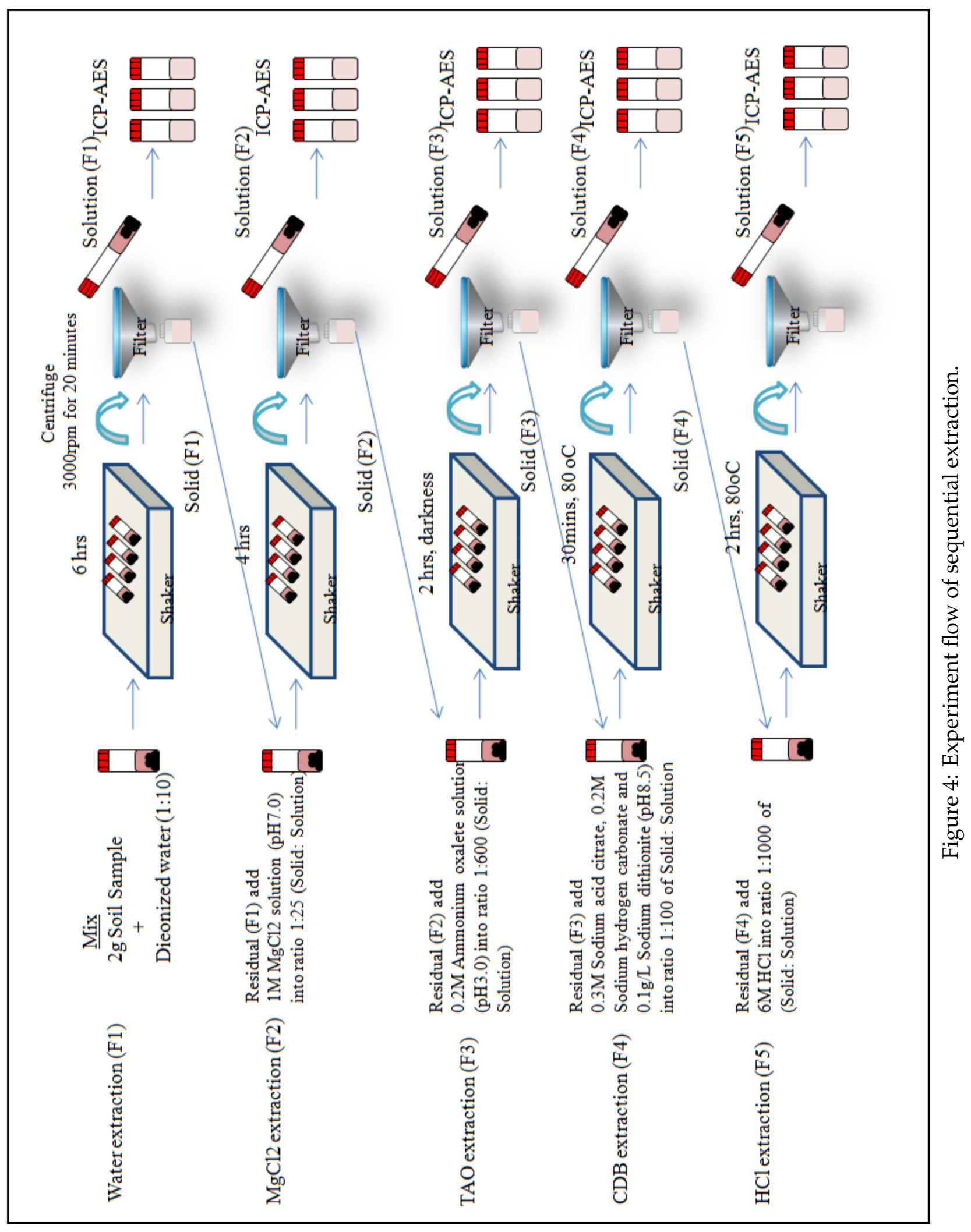


Table 3: Selective extraction scheme: (Tessier and Campbell 1988, Plassard et al, 2000 and Kennichi et al, 2008).

\begin{tabular}{|c|c|c|c|c|c|c|}
\hline Step & Method & Target & Solvent & \multicolumn{3}{|c|}{ Condition } \\
\hline $\mathrm{F} 1$ & $\begin{array}{c}\text { Water } \\
\text { extraction }\end{array}$ & Soluble ion & Deionized water(pH5.8-6.3) & $10 \mathrm{ml} / \mathrm{g}$ & $\begin{array}{l}\text { Room } \\
\text { Temp. }\end{array}$ & $6 \mathrm{~h}$ \\
\hline $\mathrm{F} 2$ & $\begin{array}{l}\mathrm{MgCl} 2 \\
\text { extraction }\end{array}$ & Exchangeable ion & $1 \mathrm{M} \mathrm{MgCl} 2$ solution(pH7.0) & $25 \mathrm{ml} / \mathrm{g}$ & $\begin{array}{l}\text { Room } \\
\text { Temp. }\end{array}$ & $4 \mathrm{~h}$ \\
\hline F3 & $\begin{array}{c}\text { TAO } \\
\text { extraction }\end{array}$ & $\begin{array}{l}\text { Amorphous, poor } \\
\text { crystalline Iron and } \\
\text { Aluminum minerals }\end{array}$ & $\begin{array}{l}\text { 0.2M Ammonium oxalete } \\
\text { solution( } \mathrm{pH} 3.0)\end{array}$ & $600 \mathrm{ml} / \mathrm{g}$ & $\begin{array}{l}\text { Room } \\
\text { Temp. }\end{array}$ & $\begin{array}{l}2 \mathrm{~h} \\
\text { (Dark } \\
\text { ness) }\end{array}$ \\
\hline $\mathrm{F} 4$ & $\begin{array}{c}\text { CDB } \\
\text { extraction }\end{array}$ & Iron minerals & $\begin{array}{c}\text { Mixed solution by } 0.3 \mathrm{M} \\
\text { Sodium acid citrate, } 0.2 \mathrm{M} \\
\text { Sodium hydrogen carbonate, } \\
0.1 \mathrm{~g} / \mathrm{L} \text { Sodium } \\
\text { dithionite }(\mathrm{pH} 8.5)\end{array}$ & $100 \mathrm{ml} / \mathrm{g}$ & $80^{\circ} \mathrm{C}$ & $\begin{array}{l}30 \\
\min \end{array}$ \\
\hline F5 & $\begin{array}{c}\mathrm{HCl} \\
\text { extraction }\end{array}$ & Clay minerals & $6 \mathrm{M} \mathrm{HCl}$ & $1000 \mathrm{ml} / \mathrm{g}$ & $80^{\circ} \mathrm{C}$ & $2 \mathrm{~h}$ \\
\hline
\end{tabular}

Table 4: Summary of metals extraction in mg per $\mathrm{kg}$ of soil.

\begin{tabular}{|c|c|c|c|r|c|c|c|r|r|r|r|r|}
\hline Soil & $\mathrm{Al}^{*}$ & \multicolumn{1}{|c|}{$\mathrm{Al}^{* *}$} & $\mathrm{Cu}^{*}$ & $\mathrm{Cu}^{* *}$ & $\mathrm{Fe}^{*}$ & $\mathrm{Fe}^{* *}$ & $\mathrm{Mn}^{*}$ & $\mathrm{Mn}^{* *}$ & $\mathrm{~Pb}^{*}$ & $\mathrm{~Pb}^{* *}$ & $\mathrm{Zn}^{*}$ & $\mathrm{Zn}^{* *}$ \\
\hline Loamy fine sand & 33800 & 85200 & 0 & 164 & 37000 & 65100 & 426 & 809 & 0 & 60 & 56.2 & 273 \\
\hline Fine sandy loam & 33000 & 102000 & 0 & 61.2 & 31800 & 44800 & 588 & 2120 & 0 & 0 & 25 & 125 \\
\hline
\end{tabular}

Note $^{*}$ all fractions $* *$ Clay fractions

Table 5: Total $\mathrm{Cu}$ obtained from amorphous iron in clay fractions.

\begin{tabular}{|l|r|r|l|r|l|r|}
\hline Sample list & \multicolumn{1}{|l|}{$\mathrm{Al}$} & $\mathrm{Cu}$ & $\mathrm{Fe}$ & $\mathrm{Mn}$ & $\mathrm{Pb}$ & \multicolumn{1}{l|}{$\mathrm{Zn}$} \\
\hline Loamy fine sand & 9120.00 & 175.80 & 17880.00 & 678.00 & $\mathrm{UDL}$ & 196.20 \\
\hline Fine sandy loam & 22140.00 & 91.80 & 23160.00 & 2382.00 & 2.70 & 78.00 \\
\hline
\end{tabular}




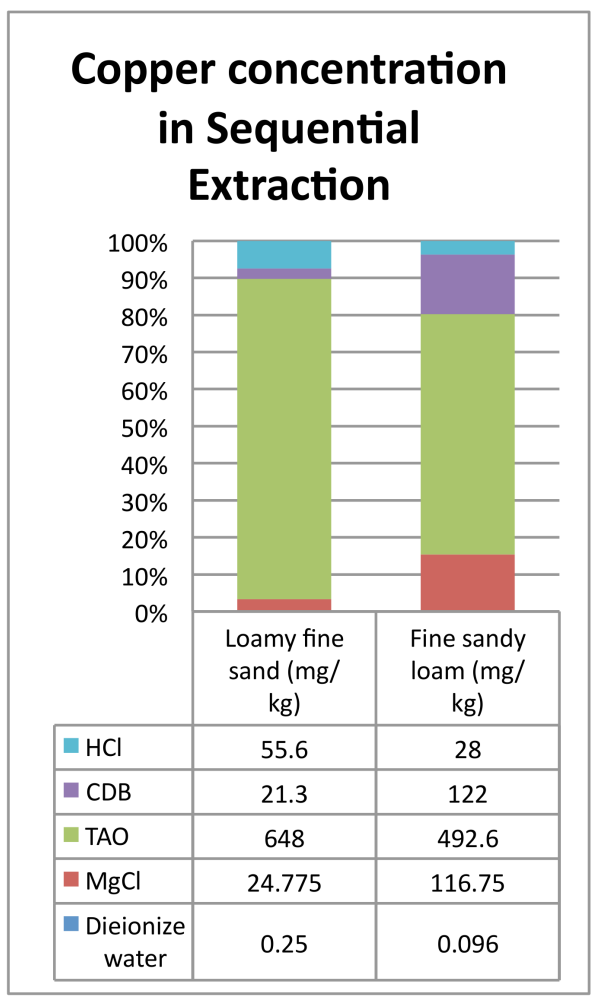

Figure 5: Distribution of $\mathrm{Cu}$ in soil after batch experiment with extraction phases.

\section{Conclusion}

Loamy fine sand and fine sandy loam from urban area at Mantrijeron, Yogyakarta, Indonesia, are good for $\mathrm{Cu}$ sorption (low mobility) with maximum $\mathrm{Cu}$ sorption capacity in loamy fine sand and fine sandy loam is $5.8 \mathrm{mg} / \mathrm{g}$ and $3.9 \mathrm{mg} / \mathrm{g}$, respectively. Cu distribution in both soil were many phases in different amount. Sequential extractions strong agree to the result from chemical extraction, which $\mathrm{Cu}$ distribution influenced by amorphous iron in clay fraction.

According to result of chemical extraction and sequential extraction, can be concluding that iron amorphous in clay fraction was influenced for $\mathrm{Cu}$ sorption (mobility) in these soil. This is advantage in environment of Yogyakarta urban area, Indonesia, where this area underlain by loamy sand soil amorphous were influenced for $\mathrm{Cu}$ sorption in this study area.

\section{Acknowledgment}

Authors would like to thank the ASEAN University Network Southeast Asia Engineering Education Development Network (AUN/SEED-Net) program under the Japanese International Cooperation Agency contribution (JICA) and Center for Engineering Education Development (CEED), Hokkaido University for financial support academic contribution to this research. Authors also have a deep of appreciation to Agriculture Center Yokohama Plant Protection Station, The Ministry of Agriculture, Forestry and Fisheries of Japan 231-0003 that gave authors a permission to bring soil to Japan. Last but not least, special thanks go to Mr. Toru Nishiuchi who gave great assisted to this research.

\section{References}

Al-Zahrani, A. A., and Abdul-Majid, M. H. (2009) Extraction of Alumina from Local Clays by Hydrochloric Acid Process. Eng. Sci. 20: 29-41.

ANZECC and ARMCANZ (2000) Australian and New Zealand Guidelines for Fresh Water and Marine Water Quality. Australian and New Zealand Environment and Conservation Council/Agriculture and Resource Management Council of Australia and New Zealand, Canberra.

Bhagure, G. R., and Mirgane, S. R. (2011) Heavy Metal Concentrations in Groundwaters and Soils of Thane Region of Maharashtra, India, Environ Monit Assess 173: 643-652.

Cabral, A. R. and Lefebvre, G. (1998) Use of Sequential Extraction in The Study of Heavy Metal Retention by Silty Soils. Water, Air, and Soil Pollution 102: 329-344.

Flores-Rodriguez, J., Bussy, A. L., and Thevenot, D. R. (1994) Toxic Metals in Urban Runoff: PhysicoChemical Mobility Assessment Using Speciation Schemes, Wat. Sci. Tech. 29: 83-93

Gibson, M. J., and Farmert, J. G. (1986) Multi-step Sequential Chemical Extraction of Heavy Metals from Urban Soils. Environmental Pollution (Series B) 11: 117-135.

Kennichi, I., Sato, T., Keisuke, F., Koichi, H., Hodaka, T., Tetsuro. Y. (2008) A Novel Remediation System Learnt from Natural Attenuation Process with Resources Retrievability for Acid Mine Drainage, Journal of MMIS 124: 519-528. 
Mullerova, H., Kruml, O., Vybihal, K., Zeman, J., and Muller, P. (2003) Adsorption of Copper and Cadmium from Aqueous Types of Sediments under Static and Dynamic Conditions. Bulletin of Geosciences 78: 169-178.

Plassard, F., Winiarski, Th., and Petit-Ramel, M. (2000) Retention and Distribution of Three Heavy Metals in a Carbonated Soil: Comparison between Batch and Unsaturated Column Studied, Journal of Contamianant Hydrology 42: 99-111.

Snape, I., Scouller, R. C., Stark, S. C., Stark, J., Riddle, M. J., and Gore, D. B. (2004) Characterisation of the Dilute $\mathrm{HCl}$ Extraction Method for the Identi- fication of Metal Contamination in Antarctic Marine Sediments. Chemosphere 57: 491-504.

Tessier, A., Campbell, P. G. C., and Bisson, M. (1979) Sequential Extraction Procedure for the Speciation of Particulate Trace Metals. Analytical Chemistry 51: 844-851.

Xaixongdeth, P., Sato, T., Karnawati, D., Hendrayana, H., and Putra, D. P. E. (2012) Unsaturated Soil Attenuation for Copper, Case study: Mantrijeron District, Yogyakarta, Indonesia (Unpublished). 